\title{
TRAUMATIC CHANGE: THE DYNAMICS OF CHARACTER AND CHRONOTOPE WHEN BAKHTIN'S 'OTHER' IS HARMFUL
}

\author{
Lorinda Tang | Deakin University
}

\begin{abstract}
Bakhtin's world is predicated on the identity forming paradigm of self and other in dialogue. This dialogue occurs within the chronotope-the time-space-unique to the self. Yet this world does not consider the impact of trauma on the self, nor the way in which traumatic change shifts identity, and informs the relationships between self-chronotope and self-other. Reading concepts of literary trauma theory into Bakhtin's world enables writers to create resonant characters that meaningfully depict the lived experience of trauma.
\end{abstract}

BIOGRAPHICAL NOTE

Lorinda Tang is an Adelaide based writer of fiction and short stories. She has an extensive background in professional and legal writing. Before focusing on her writing career, Lorinda worked as a nurse and a lawyer. This experience underpins her concern with the ethics of creative writing, and the way in which intimate life events are explored. Lorinda is currently pursuing a $\mathrm{PhD}$ through Deakin University.

KEYWORDS

Bakhtin-Dialogic-Self-Other-Chronotope-Trauma 
In this paper I will examine how a traumatised protagonist can be crafted within the framework of Bakhtin's dialogic world and the chronotope, and how the concepts of literary trauma theory may inform a traumatised protagonist's view, voice and evolution. I will show how these concepts operate with examples from classic nineteenth century literature, as the reader's familiarity with these texts will make the theory more accessible. I will refer to modern texts for additional emphasis. $^{*}$

The traumatised protagonist presents two challenges to Bakhtin's dialogic world. Firstly, if the traumatic event experienced by the protagonist was an act of harm by another person, rather than an accident, the traumatised protagonist does not fit into Bakhtin's identity forming paradigm of self and other. Secondly, the traumatised protagonist does not fit into a definitive chronotope, or exist entirely in their once only, unique place of existence.

My original question for this paper was whether there is room for trauma in Bakhtin's dialogic world. This has evolved into: how can an author ethically represent a traumatised protagonist within Bakhtin's dialogic world?

\section{Self and other}

Bakhtin conceives the self and other as dialogic. In Author and Hero in Aesthetic Activity he explores the relationship between author and hero as a metaphor for the relationship between self and other (Hicks 2000: 233). In this work, Bakhtin considers the self spatially and temporally, a precursor to his preoccupation with time-space and the way in which character relates to chronotope.

Because they are in dialogue, self and other are co-dependent. Bakhtin states:
A human being experiencing life in the category of his own $I$ is incapable of gathering himself by himself into an outward whole that would be even relatively finished (1990: 35$)$.

This co-dependence is the foundation of Bakhtin's theory that the self is built and evolves through relationship: we are dependent on the other to become aware of our self (Hicks 2000: 233). The extent of this dependence is extreme: 'this outward personality could not exist, if the other did not create it' (Bakhtin 1990: 36). Part of the difficulty in seeking to create a self without the other is that, as Bakhtin claims, the self alone cannot see or approach itself in a 'unitary axiological' manner (1990: 35). That is, there is no method or system of value, 
ethically or aesthetically, with which to view, assess, or imbue the self. Thus, the other attributes our value to us, and we construct our sense of worth through this relationship. As Holquist states it, 'the subject at the heart of identity, the agent of perception, is invisible to itself' (2010: 30).

Bakhtin further highlights the existential nature of this dependence by demonstrating that our cognition is limited by our perception. He calls this an 'excess of seeing', though I suggest it could be inverted to the 'limits of our seeing'. He states:

When I contemplate a whole human being who is situated outside [...] me, our concrete, actually experienced horizons do not coincide. For at each given moment, regardless of the position and proximity to me of this other human being [...] I shall always see and know something that he [...] cannot see himself $[\ldots]$ the world behind his back, and a whole series of objects and relations $[\ldots]$

[...] the excess of my seeing must 'fill in' the horizon of the other human being who is being contemplated, must render his horizon complete, without at the same time forfeiting his distinctiveness [...] I must enframe him, create a consummating environment for him out of the excess of my own seeing, knowing, desiring, and feeling (Bakhtin 1990: 22 - 23, 25).

In simple terms, when a person is alone, looking outwards, they see a horizon. It is only when there is an other looking back at them that an environment is created, through a merging of the self and other's excess of seeing, and the juncture of their different horizons (Bakhtin 1990: 97, 98, 25).

In creating an environment, the self and other experience transgredience: the projection of the self beyond the boundaries of the body, into the other, an assimilation with the other, appropriation of the other's 'concrete life-horizon', and a return to the self (Bakhtin 1990: 25). An ideal form of this transgredience is termed 'sympathetic co-experiencing' by Bakhtin.

Sympathetic co-experiencing is what occurs when we engage with the other with empathy and compassion. It is an ethical act. Bakhtin refers to it as an act of loving recognition that is needed to the degree that it 'shatters [...] selfsufficiency' (Bakhtin 1990: 50). By sympathetic co-experiencing we become visible to ourselves.

This raises the first problem of the traumatised protagonist in Bakhtin's world. Bakhtin's view of the other is benevolent. He paints the other as the loving mother, as the person who gifts grace through a recognition of our value (Bakhtin 1990: 50). Bakhtin's sympathetically co-experiencing 'other' does not 
'deal with the ways in which an agent can envelop his or her subject in a destructive value context' (Hicks 2000: 234). Because he does not consider this harmful other, Bakhtin is also silent on the traumatised self and the implications of trauma for identity.

This is a problem where interpersonal trauma occurs. Bakhtin notes that one can never see one's self, nor the space one occupies, without the other. Even a mirror corrupts the image of the self because the self will perceive with eyes like the other, or the body will assume a position or expression presumed to appeal to the other (Bakhtin 1990: 33; and 1984: 59). The harmful other, therefore, dictates to the self a corrupted image and a flawed identity. Consider Oscar Wilde's The Picture of Dorian Gray. Lord Wotton, a harmful other, sets out to corrupt Dorian and is successful (Wilde 2016: 34 - 35). Basil, a benevolent, but not disinterested other, sees Dorian as an aesthetic marvel (Wilde 2016: 16). The narrative focuses on the juxtaposition of the way in which Dorian is seen in person as opposed to how he is seen in the picture. There is irony in this instance, as Dorian has the benefit of an actual view of himself as an other (Basil) sees him via the picture, whilst his self-view, in the mirror, is erroneous.

What does the self experience when the other harms it? Bakhtin makes an essential differentiation between the legal self, the external body which comprises a legal personality, and the experience of the inner self. This distinction is important because injury that occurs to the body or legal person is clear and definable. Those actions are understood within the social contract as rights and obligations. Bakhtin states there is:

An equally profound difference between my inner experience of my own body and the recognition of its outer value by other people - my right to the loving acceptance or recognition of my exterior by others [...] descends like a gift, like grace [...] [and] is incapable of being understood and founded within myself (Bakhtin 1990: 49).

Trauma to the self is characterised by its existential elements and differs to trauma to the body. Trauma to the self is an injury to the essence of our being; it is an ontological assault.

An example of this can be found in Charlotte Bronte's Jane Eyre. In describing her childhood, Jane states that John Reed 'bullied and punished me [...] continually: every nerve I had feared him, and every morsel of flesh on my bones shrank when he came near' (Brontë 2007: 8). When she is consigned to the Red Room, Jane suffers further trauma: 'all John Reed's violent tyrannies, all his sisters' proud indifference, all his mother's aversion, all the servants' partiality, turned up in my disturbed mind' (Brontë 2007: 16). In this state, she 
experiences, based on a misperception, and possibly due to a concussion, 'a vision from another world [...] I was oppressed, suffocated: endurance broke down' (Brontë 2007: 16 - 17). Heartlessly, Mrs Reed leaves Jane locked in the room despite her pleas. These early others, despite Jane's own astute sense of justice, deeply harm Jane. In the aftermath, it is the 'fearful pangs of mental suffering', rather than any physical injury, that is formative (Brontë 2007: 21).

We see that Jane, while resilient, remains deeply affected by her early other when she returns to assist Mrs Reed. Brontë recognises that Jane's conscientious attendance does not arise from duty alone (having been a 'burdensome' charity child), but as a statement of her survivor status and the reestablishment of her sense of self: 'Love me, then, or hate me, as you will [...] you have my full and free forgiveness: ask now for God's; and be at peace' (Brontë 2007: 287; see also 276 - 277, 285 - 286).

Jane's conduct demonstrates that Mrs Reed, as an other, no longer has power over her self. While she is, as yet, unfinalised, Jane has had sufficient experience of benevolent, or restorative others, to free her self (see Jane's relationship with Miss Temple at Lowood: Bronte 2007: 79, 84-85, 101 - 102).

Without the other, the self has no cognitive basis on which to construct its identity. Furthermore, without an ethical other, or a sympathetically coexperiencing other, any self that does form will be fundamentally flawed due to the harmful perceptions or cognitive processes introduced by the other.

In Remembering Babylon, David Malouf captures this devastating phenomenon metaphorically in his final portrait of Gemmy, who has survived a traumatic childhood, but never found a benevolent or restorative other:

He still carried in his pocket the sheets of paper on which they had written down his life. He took them out now. They were sodden. Rain had begun to wash the writing from them, the names, the events; their black magic now a watery sky-colour, the sooty grains sluicing away even as he watched; the paper turned pulpy, beginning to break up in his hands, dropping like soggy crumbs from his fingers into puddles where he left them, bits all disconnected [...] (Malouf 1994: 165).

\section{Chronotope}

Another significant consequence of trauma to the self is that the harmful other can sever the self's connection to the chronotope. The term 'chronotope' is 
literally time-space, and Bakhtin borrowed from Einstein's theory of relativity to coin it 'almost, but not quite, as a metaphor' (1981: 84).

In Forms of Time and the Chronotope in the Novel Bakhtin explains his theory of the chronotope and its application:

In the literary artistic chronotope, spatial and temporal indicators are fused into one carefully thought-out, concrete whole. Time [...] thickens, takes on flesh, becomes artistically visible; likewise, space becomes charged and responsive to the movements of time, plot and history. This intersection of axes and fusion of indicators characterizes the artistic chronotope (Bakhtin 1981: 84).

Here, Bakhtin is postulating that it is the chronotope that takes narrative from the form of when-where-what to a storyworld that is inhabitable, mobile and responsive.

The chronotope is not limited just to the time-space of mere setting: it is also infiltrated by the historical, social and experiential qualities of the time-space. Steinby calls the chronotope 'the representation of [...] cognition or experience in [temporal-spatial form] in literature' (2013: 106). Essentially, the chronotope should be understood epistemologically. They are venues of perception, forums for cognition, arenas for action, and scaffolds of meaning.

The chronotope also defines the time-space of possible action for characters in narrative 'conditioned by a locality or social situation, but [it] still leaves the individual the freedom of ethical choice' (Steinby 2013: 122). The chronotope is not just about what we know and understand, but how we make meaning to act ethically.

In the chronotope, a character moves through a cycle of perception-cognitionaction, with each element being linked by the values deduced and applied. It is the chronotope that allows us to understand why the character may think a certain way about what they observe, or what in character's psyche prompts them to behave a certain way. These details become implicit in the narrative when a chronotope is effective. It is why we can understand, for example, the predicament of Tess Durbeyfield as Alec D'Urberville intercepts her and drives her to The Slopes. Through the chronotope of the road, and D'Urberville's deliberately reckless driving to frighten and coerce Tess, we understand that this journey is literal and metaphorical:

Safe, thank God, in spite of your folly!' said she [...] He loosed rein, and away they went a second time [...] he urged the horse anew, and rocked 
her the more. 'Will nothing else do?' she cried at length, in desperation, her large eyes staring at him like those of a wild animal [...] He was inexorable, and she sat still, and D'Urberville gave her the kiss of mastery (Hardy 1998: 53 - 57).

The road chronotope figures again at the point of Tess's undoing, with D'Urberville following her from Chaseborough, convincing her to mount his horse with him, and then taking the road to The Chase woods, where they are both lost (Hardy 1998: 64 - 74). In these scenes the reader appreciates that Tess is powerless: she is a passenger, she cannot choose the road or direct the way in which it is taken. The reader can appreciate the literal, psychological and metaphorical point to which the relationship has come because as they have traversed the time-space of the roads the manner of their going has revealed to us their characters through the ways in which they have perceived, thought and acted.

By way of further example, the chronotope of the arena is used to great effect in Suzanne Collins The Hunger Games (2008), Catching Fire (2009), and Mockingjay (2010). The arena, with all that is implicit to its idea of spectacle, and excess, and heightened sensation, is deployed effectively to explore the lived experience of Katniss Everdeen. The arena is also neatly manoeuvred into a 'nested' chronotope as the reader, and Katniss, come to realise that all of Panem is an arena. The novels also demonstrate, through the function of the arena, that trauma is not contained by, or confined to, the time-space of experience.

As a literary device, it is the chronotope that 'translates' abstract ideas into 'sensual descriptions and ontological circumstances' (Ladin 1999: 212). Bakhtin claims that:

[...] the chronotope, functioning as the primary means for materialising time in space, emerges as a centre for concretising representation, as a force for giving body to the entire novel. All the novel's abstract elements - philosophical and social generalisations, ideas, analyses of cause and effect - gravitate towards the chronotope and through it take on flesh and blood, permitting the imaging power of art to do its work (1981: 250).

The self (or protagonist) in the chronotope is bound up in the abstraction of meaning, seeking validation, and making ethical judgments. In portraying a traumatised protagonist, the ability to delineate these factors may be blurred due to the effect of the harmful other on the protagonist's ability to know what they see, and the influence of the other on the protagonist's actions. An important question in depicting the traumatised protagonist is communicating 
when, and to what extent, they are a free agent. Chronotopic motifs can be useful to indicate this.

Attention should be paid to the chronotope as experienced by the protagonist for two reasons. Firstly, because even in the same event, we all experience it differently. Not only do we physically occupy a different space, with its own horizon, 'but we also regard the world and each other from different centres in cognitive time/space' (Holquist 1999: 101). It is impossible to identify a chronotope without understanding whose consciousness is representing the chronotope; it is the self's consciousness of time and space that constructs the chronotope.

To demonstrate the applicability of the chronotope to literary trauma theory I will now consider how key exponents of trauma theory explain the experience of time, and its disruption, during trauma. I will then consider specific challenges for fiction writers of traumatised protagonists and characters.

\section{Trauma theory}

Trauma, in Caruth's work, is understood as belated experience:

The [traumatic] event is not assimilated or experienced fully at the time, but only belatedly, in its repeated possession of the one who experiences it (Caruth 1995: 4).

The power of trauma's 'possession' of the survivor, according to Caruth, is that 'through its inherent forgetting is [when the trauma is] first experienced at all' (1996: 18). This understanding of trauma relies on the idea of an absence or unconsciousness during the traumatic event. This is dissociation: a dislocation in time-space during the traumatic event that is repeated when the event is recalled. Because of this dissociation, there is no referentiality to the traumatic event, and the experience becomes cognitively unavailable (Balaev 2016: 5). The conclusion is that the survivor therefore experiences 'cognitive chaos and the possible division of consciousness' (Balaev 2008: 150). Essentially, the survivor's psyche is characterised by dissociated memories, with gaps or absences in consciousness, and untimely re-experiences of the trauma (Radstone 2007: 20).

In Bakhtinian terms, during trauma while the physical body is present, the self is 'elsewhere': it cannot perceive and therefore has no cognition. During reexperience of the trauma, the self is present in an altogether different 
chronotope, but experiences the past events, still nested in the prior chronotope, as an interloper in the present. In both cases, the self is unable to fulfil its obligation to relate to the world, as the occupant of their unique, onceonly place. Bakhtin predicts that this failure leads to chaos. Psychologically, this is correct, as seen through traumatic sequelae such as Post-Traumatic Stress Disorder, which is characterised by anxiety, hypervigilance, flashbacks, nightmares, dissociation, and on occasion, a fugue state or multiple personality disorder (Leys 2000: 231 - 233).

Kurt Vonnegut, in Slaughterhouse 5 (2000), depicts this experience by untethering Billy Pilgrim's narrative voice from time and space so that he slides between past, present and delusion. The phrase 'so it goes' becomes a refrain as Billy slides from one chronotope to another. His drifting is a result of the trauma causing chaos at the time it occurs in the original chronotope, and at the moment when the trauma is triggered and repeated.

In A Tale of Two Cities, Charles Dickens poignantly denotes the loss of self caused by dissociation in the images of Dr Manette when we first meet him making shoes:

So he sat, with a steadfastly vacant gaze, pausing in his work. He never looked at the figure before him, without first looking down on this side of himself, then on that, as if he had lost the habit of associating place with sounds; he never spoke, without first wandering in this manner, and forgetting to speak [...] The task of recalling him from the vacancy into which he always sank when he had spoken, was like recalling some very weak person from a swoon, or endeavouring, in the hope of some disclosure, to stay the spirit of a dying man [...] No human intelligence could have read the mysteries of his mind, in the scared blank wonder of his face [...]' (Dickens 1985: 71-81).

Dr Manette relapses after Lucie's marriage, triggered by the revelation that Charles Darnay is Charles Evrémonde, the child of the man who imprisoned him. On this occasion, Mr Lorry 'observed a great change to have come over the Doctor; as if the golden arm uplifted there, had struck him a poisoned blow' and then '[...] it was the old scared lost look [...] even the old haggard, faded surface of face had come back to him' (Dickens 1985: 223 - 224). This provides a strong example of how trauma makes one absent in one chronotope while present in another and vice versa (after Lucie's wedding Dr Manette is physically present in Soho but mentally absent; he is mentally present in the Bastille). It also exemplifies how the self becomes incapable of perception-cognition-action in traumatic contexts: Dr Manette is completely disabled by the trauma, to 
the degree that he experiences confusion in finding doors unlocked or open.

Another modality of trauma is characterised as 'retrodetermined' trauma, and this is particularly relevant to trauma caused by the harmful other. In this situation, an event may not be experienced traumatically, but Forter states:

[...] a word, an observation, the sensory perception, a feeling - something in the person's present life sets off a chain of associations that leads to the first scene's unconscious understanding giving rise to intense anxiety precisely by making that scene significant and rendering it traumatic for the first time (Forter 2007: 264).

Charles Dickens shows us this retrodetermined trauma in Great Expectations. Pip is the beneficiary of funds from an unknown source and lives in expectation of them. On discovering that the money has come from Magwitch, an escaped convict that a much younger Pip had aided, Pip is horrified and distressed-that is, traumatised-and cannot continue to accept the funds (Dickens 2012: 2, 9 11, 201 - 206). The trauma is exacerbated by Magwitch's return from Australia and the onus on Pip to assist his escape or see him captured and hung (Dickens 2012: $206-212,236-239,242-243)$.

From this perspective, a trauma also flummoxes the survivor's ability to exist meaningfully in the chronotope. The original scene is rendered innocent and for whatever reason, the self is unable to perceive or cognitively recognise that they have been in a traumatic event. They are not functionally existing in the chronotope as an epistemological and ontological structure. The late awareness that the event was traumatic means the traumatic experience occurs, again, in a different time and place, in response to a different stimulus.

We know that 'traumatic experiences disrupt attachments between self and others by challenging fundamental assumptions about moral laws and social relationships that are themselves connected to specific environments' (Balaev 2008: 160). Compounding that loss of relationship is the impact of dissociation and displacement in time-space. In this situation, the self is unable to construct its identity because there is no 'other' in its re-experience of the traumatic event; the other who harmed them is not actually present in the delayed experience of trauma. Similarly, the survivor is also isolated, quarantined even, from an other who is present at a time when flashback or other re-experience occurs, because even if that other seeks to sympathetically co-experience with the survivor, they can only experience the present event; they are forever prevented from coming alongside the survivor in the original traumatic event. This points to one of the flaws in the talking cures, in testimony and witness, as constructs of trauma. 
Literary trauma theory has relied on 'unspeakability', so that, in giving testimony or witness to trauma, it glosses over, or paraphrases the event, and the aftermath (Stampfl 2014: $16-20$ ). ${ }^{1}$ The self is also confronted with an 'unspeakable' experience, because its cognition is affected, the horror is too great for words, or it fears disbelief or retribution for speaking. Aside from these personal perspectives, an essential concern for speaking trauma, or representing the traumatised protagonist, is to determine whether survival has a mimetic or anti-mimetic paradigm (Leys 2000: 299).

In the mimetic paradigm, trauma 'can be understood as involving a kind of hypnotic imitation or identification in which, precisely because the victim cannot recall the original traumatogenic event, she is fated to act it out, or in other ways imitate it' (Leys 2000: 298). Underpinning this imitation or repetition is a presumed moment where the survivor identifies with the perpetrator and appropriates the perpetrators 'hostility' towards its self (Leys 2000: 299). With this view, not only do the involuntary qualities of PTSD repeat, but also, potentially, acts and behaviours associated with the traumatic experience are repeated. A serious implication of this is the possibility that in the traumatic absences the self lacks autonomy and accountability (Leys 2000: 9).

In contrast, the anti-mimetic theory suggests the trauma is an 'unassimilable event which is dissociated from memory' and sees the survivor as 'aloof from the traumatic experience' with the traumatic stimuli being experienced as something entirely outside the self (Leys 2000: 299). In this view, the traumatised protagonist experiences the dissociation of trauma as more an 'out of body' type experience, does not identify with the perpetrator and may also be unable to identify with themselves. Leys suggests that the flaw in trauma theory is the assumption that the question is binary (2000: 299). In this regard, I suggest that a Bakhtinian approach, where the mimetic and anti-mimetic approaches are in dialogue, would better represent the lived experience of trauma.

Literary trauma theory, as it currently stands, does not fit comfortably into either the mimetic or anti-mimetic paradigm as there are elements of both present. As writers of traumatised protagonists this leaves scope for narrative decision making, such as narrative structure, play of registers and tropes.

However, the sinister moment in the mimetic paradigm, where the survivor identifies with the perpetrator and the perpetrator projects their guilt and shame onto the survivor, is evocative of trauma caused by the other. This dynamic is also indicative of what happens to the self and other where 
transgredience is not sympathetic co-experiencing, but invasive perceptual distortion and cognitive disruption. Examples of this process include gaslighting ${ }^{2}$ and victim blaming.

I posit that the traumatised protagonist may experience trauma in both paradigms and should be written 'case by case', with each traumatised protagonist distinguishable, because trauma is always experienced in isolation: even shared traumas are lived singularly. Trauma must leave traces that fundamentally and uniquely affect the character and narrative: the character must 'become' a self through some form of change, such as coping or recovery. As Bakhtin would say, this means returning to one's unique time and place, renouncing the 'elsewhere' and making meaning of the experience. It is the process of becoming, of making meaning, that matters rather than seeking closure or healing which are misnomers to the survivor. This view is based on the premise that the experience of trauma caused by the other is not only subjective; it is personal. The other, and witnesses to trauma, fit more comfortably into the anti-mimetic paradigm, as subjects 'fully constituted' and 'aloof' (Radstone 2007: 15).

The problem with the current depiction of trauma in fiction is that it falls into what Bakhtin would call 'adventure time' where the hero has some event occur that does not really leave a mark, or change the character, as though time stops just before the traumatic event, recommences after it, and it is as though nothing has happened (1981: 91). This superficial treatment of a complex psychological process does not do justice to the narrative, the character, a writer's literary scope, or readers who are trauma survivors.

\section{Conclusion}

Bakhtin's view of the self is that it is unfinalisable. In a sense, he answers the question about trauma and the identity on the self:

[...] insofar as I find precisely myself in a given lived experience, insofar as I do not renounce it as my own within the unique unity of my own life, I connect it with the future - the future of meaning. I render it unindifferent to this future, I transpose its definitive justification and accomplishment into what-is-yet-to-be [...]; as long as I am the one living in it, it does not yet exist in full (Bakhtin 1990: 117).

The reason why Bakhtin was focussed on the benevolent other is not clear, especially as in his life he experienced exile, an event that was traumatic. I 
suggest that he neglects the idea of an other who is not benevolent either because he was more concerned with the ethical self, or because his own meaning making could not accommodate an other that was not loving. This latter reason is based on the fact that while his writing is 'compartmentalised', he was a theist, and he refers to concepts such as grace and love in his philosophical works. Furthermore, his primary work on self and other is constructed as Author and Hero: Creator and Creation.

As writers, it is possible to create a traumatised protagonist that is ethically represented and accurately drawn because-and this is an assumption-in the act of creating their protagonist a writer will seek to sympathetically coexperience, and will confer form upon them as a loving act of parent-child. In those first moments the child knows they are a self.

An essential aspect to that ethical representation is to draw the traumatised protagonist with meticulous care, including their suspension across time-space, as this is their lived experience. Through the whole narrative, the cognitive dissonance of the protagonist's being, their struggle to resume becoming, and the chaos created by clashing chronotopes filled with historicity, social and psychological indicators, are essential elements to plot and character. Writers do great service to the human spirit by crafting narratives that are rich in textures and imagery that evoke what the lived experience of trauma means for the self that survives.

\section{Acknowledgement}

I gratefully acknowledge the suggestions of the peer reviewers regarding this paper. I especially appreciate being directed to Amitav Ghosh's The Great Derangement (2016) which analyses the silence of mainstream literature on climate change. According to Ghosh, this silence, verging on wilful ignorance, is indicative of a complicity in society, including the avant garde of literature, in the face of serious environmental and humanitarian crises. To my mind, there is a direct correlation to how trauma, and more particularly, how violence against women is written: Ghosh's thesis on the obligation of writers to address climate change could be similarly applied to writers regarding trauma. The current zeitgeist of \#metoo and \#timesup is indicative of how our changing social climate is outpacing literary expression. 


\section{Endnotes}

1. Yann Martel's Life of Pi (2001) exposes the tendency to prefer the 'unspeakable', and Marguerite Duras, in The Lover (1985) and then The North China Lover (1992), exposes the tendency to 'selectively tell' because the truth is unspeakable. Unspeakability, as a narrative device and/or as a result of trauma, is the focus of my next paper.

2. 'Gaslighting' is a term derived from the play Gas Light by Patrick Hamilton (1938) in which a husband psychologically manipulates his wife by dimming the gas lights. To 'gaslight' someone is to manipulate their perception of reality.

\section{Works Cited}

Bakhtin, Mikhail M 1981 The Dialogic Imagination: four essays by M M Bakhtin M Holquist (ed) C Emerson and M Holquist (trans) Austin: University of Texas Press

Bakhtin, Mikhail M 1984 Problems of Dostoevsky's Poetics C Emerson (ed and trans) Minneapolis: University of Minnesota Press

Bakhtin, Mikhail M 1986 Speech Genres and Other Late Essays, C Emerson and M Holquist (eds) VW McGee (trans) Austin: University of Texas Press

Bakhtin, Mikhail M 1990 Art and Answerability: early philosophical essays by $M M$ Bakhtin M Holquist and V Liapunov (eds) V Liapunov (trans) Austin: University of Texas Press

Balaev, Michelle 2008 'Trends in Literary Trauma Theory' Mosaic: An Interdisciplinary Critical Journal 41 (2), 149 - 166

Balaev, Michelle 2014 'Literary Trauma Theory Reconsidered' M Balaev (ed) Contemporary Approaches in Literary Trauma Theory, New York: Palgrave McMillan, 1 - 14

Bemong, Nele and Pieter Borghart 2010 'State of the Art' N Bemong, P Borghart, $\mathrm{M}$ De Dobbeleer, K Demoen, K De Temmerman and B Keunen (eds) Bakhtin's Theory of the Literary Chronotope: Reflections, Applications, Perspectives Gent: Academia Press, 3 - 16

Bocharev, S 1999 'The Event of Being: on Mikhail Mikhailovich Bakhtin' in C Emerson (ed) Critical Essays on Mikhail Bakhtin New York: G. K. Hall \& Co.

Brontë, Charlotte 2007 Jane Eyre London: Vintage (Random House)

Caruth, Cathy 1995 Trauma: Explorations in Memory Baltimore: John Hopkins University Press

Caruth, Cathy 1996 Unclaimed Experience: Trauma, Narrative and History Baltimore: John Hopkins University Press

Collins, Suzanne 2008 The Hunger Games Sydney: Scholastic Press

Collins, Suzanne 2009 Catching Fire Sydney: Scholastic Press

Collins, Suzanne 2010 Mockingjay Sydney: Scholastic Press

Dickens, Charles 1985 A Tale of Two Cities London: Penguin Group 
Dickens, Charles 2012 Great Expectations New York: Vintage Books (Random House)

Duras, Marguerite 1985 The Lover Barbara Bray (trans) New York: Pantheon Books (Random House)

Duras, Marguerite 1992 The North China Lover Leigh Hafrey (trans), New York: The New Press

Forter, Greg 2007 'Freud, Faulkner, Caruth: Trauma and the Politics of Literary Form' Narrative, 15 (3), $259-285$

Ghosh, Amitav 2016 The Great Derangement, Chicago: The University of Chicago Press

Hardy, Thomas 1998 Tess of the D’Urbevilles London: Penguin Group

Hicks, Deborah 2000 ‘Self and Other in Bakhtin's Early Philosophical Essays: Prelude to a Theory of Prose Consciousness' Mind, Culture, and Activity 7 (3), $227-242$

Holquist, Michael 1999 “'Otherness': Polyphony, Dialogue' C Emerson (ed), Critical Essays on Mikhail Bakhtin New York: G. K. Hall \& Co.

Holquist, Michael 2010 'The Fugue of Chronotope' N Bemong, P Borghart, M De Dobbeleer, K Demoen, K De Temmerman and B Keunen (eds) Bakhtin's Theory of the Literary Chronotope: Reflections, Applications, Perspectives Gent: Academia Press, 19 - 34

Ladin, Joy 1999 'Fleshing out the Chronotope' C Emerson (ed) Critical Essays on Mikhail Bakhtin New York: G. K. Hall \& Co.

Leys, Ruth 2000 Trauma: A Genealogy Chicago: University of Chicago Press

Malouf, David 1994 Remembering Babylon London: Vintage (Random House)

Martel, Yan 2001 Life of Pi New York: Mariner Books (Houghton Mifflin Harcourt)

Morson, Gary 2010 'The Chronotope of Humanness: Bakhtin and Dostoevsky’ N Bemong, P Borghart, M De Dobbeleer, K Demoen, K De Temmerman and B Keunen (eds) Bakhtin's Theory of the Literary Chronotope: Reflections, Applications, Perspectives Gent: Academia Press, 93 - 110

Radstone, Susannah 2007 'Trauma Theory: Contexts, Politics, Ethics' Paragraph, 30 (1), $9-29$

Stampfl, Barry 2014 'Parsing the Unspeakable in the Context of Trauma' M Balaev (ed) Contemporary Approaches in Literary Trauma Theory New York: Palgrave McMillan, 15 - 41

Steinby, Liisa 2013 'Bakhtin's Concept of the Chronotope: the viewpoint of and acting subject' L Steinby and T Klapuri (eds) Bakhtin and his Others:

(Inter)subjectivity, chronotope, dialogism London: Anthem Press

Vonnegut, Kurt 2000 Slaughterhouse 5 London: Vintage (Random House)

Wilde, Oscar 2016,The Picture of Dorian Gray London: Vintage (Random House) 